\title{
THE CONCEPT OF MAN IN AHMAD ASRORI'S ANTHROPOLOGY OF TASAWUF
}

\author{
Abdul Kadir Riyadi \\ UIN Sunan Ampel, Surabaya - Indonesia | riyadi.abdulkadir@gmail.com
}

\begin{abstract}
: this paper aims at introducing a new approach in the study of man called the anthropology of tasawuf. It combines two ways of thinking. The one looks at man rationally while the other spiritually. In the proposed approach, man is defined as both knowing and spiritual being. This kind of approach is a form of critic against the currents of thought which look at man only positively, and other intuitively. The former is duly represented by most although not all- Western scholars, while the latter by most Sufis. The new approach is also a kind of reminder that tasawuf cannot always be looked at simply and exclusively in terms of its practices and ritualism. It is above all, a discourse and system of knowledge. By bringing forward the thought of Surabaya-based sufi master named Ahmad Asrori, the paper tries to show 1) what the anthropology of tasawuf is all about, and 2) what tasawuf actually has to say concerning man and his essence. The new approach also relates the notion of man and his essence with the idea of how he acquires knowledge. Hence, it speaks not only of man ontologically but also epistemologically. In another sense, the paper is also an effort to introduce to the outsiders that tasawuf in Indonesia -which is particularly associated with Ibn Arabian tradition- is dynamic and growing.
\end{abstract}

Keywords: anthropology of tasawuf, concept of man, Ahmad Asrori

\section{Introduction}

The problem of man has captured the attention of scientists of different specialties across centuries. Many of them have proposed methods and approaches to help us understand the concept of man, and have -in one way or another- contributed to the uncovering of its 
manifold manifestations. Yet the notion of man still leaves many mysteries unanswered and waits for more effort to unearth them. The challenge to provide sufficient elaboration concerning men becomes even more formidable in this modern era, particularly because men are living in a time of vulnerability due to the pressure of modernity. Hence, man is -borrowing "Alī Sharīati - the "ever-evolving being", whose aim it is to search continuously for meaning in the constantly changing situation.

In an effort to understand the notion of man, scientists have introduced many forms of approaches -hence of sciences- the most early of which being biology, economics and linguistics. Biology deals with man as being capable of receiving psychological as well as social stimuli. It also speaks of man in terms of his reaction to the surrounding, his adaptation, and conscious effort to act in an orderly manner.

Economics in the meantime, deals with man within the context of his needs, wants and interests. These three areas receive most intense attention not only from the economists but also from researchers of other disciplines. Due to the fact that needs, wants and particularly interests are inherently linked to conflict, economics also tries to offer views and narratives concerning the management and resolution of conflict.

Linguistics on the other hand, speaks of man in terms of his continuous search for meaning. Meaning in this context is understood as the ultimate purpose of one's life without which life would be meaningless. Language in the whole process of man's search for meaning is both the medium and symbol of ideas and thought. Man can be deemed "rational" so long as he is capable of speaking out his ideas through the medium of language. Linguistics also studies symbol and treats it as part of meaning inherent within language.

Hence, the three sciences are the most fundamental tools through which we can learn about man and what constitutes him most as a living being. Biology informs us about man's function and norm, economics about his basic needs and interests, conflicts that surround them as well as the laws that regulate them, while linguistics tells us about the system of meaning and symbol. Taken them in their totality,

1 Ali Shari'ati, Tugas Cendikiawan Muslim, ttansl. Amin Rais (Jakarta: RajaGrafindo Persada, 2001), p. 28. 
these sciences are sufficiently informative about all that we need to know concerning man. ${ }^{2}$

Apart from the three sciences above, other sciences that have dealt with the problem of man include psychology, sociology and most importantly anthropology. The later -anthropology- is the most serious and intensive of them all. It dedicates itself to explore the world of man particularly from cultural as well as -and this is our concern- philosophical point of view.

Anthropology was initially a science introduced and appropriated by the colonial powers in a way to understand the nature of the colonized object and ultimately to justify their colonization. Earlier, it was a science that deals merely with fossils and the racial origin of human being. In due time, it develops into a sophisticated science capable of being used as a methodological tool to investigate various issues concerning man and his nature. Due to its flexibility however, anthropology -as this paper tries to do- can also be merged into such Islamic sciences as tasawuf, which is none other than the spiritual dimension of Islam.

This paper, by referring to the thought of Surabaya-based sufi Ahmad Asrori is interested in exploring further the notion of man from the perspective of the so-called Anthropology of Tasawuf, namely the amalgamation of anthropology, which represents rationality and tasawuf, which represents spirituality.

\section{On the Anthropology of Tasawuf}

Anthropology is varied. One may speak of -for instance- social and philosophical anthropology. In this paper, what is referred to as anthropology is the latter one. By philosophical anthropology, we mean that which assumes man as a rational being. In this definition, man is studied philosophically as an existent that have within him elements that make him rational. He is not merely material being. By extension, man is also spiritual because it is his spirituality that leads ultimately to his rationality. ${ }^{3}$

\footnotetext{
2 Michel Foucault, The Archaeology of Knowledge and the Discourse of Language, transl. AM Sheridan Smith (London: Routledge, 1969), p. 198.

${ }^{3}$ The most leading scholars who advocates the notion of philosophical antropology is Thomas Aquinas of the classical era and Michel Foucault in the modern time. Aquinas is well-known for his concept of Human Nature within which he exposes the relation between mind and body as well as between intentionality and human action. See
} 
Being rational, man is deemed as having a very high position in the whole system of universe. Islam regards man as God's most important creature. Similarly, philosophical anthropology believes that man is the most perfect reflection of God's omnipotence. This approach sees man as comprising of body and soul, heart and mind, rationality and spirituality.

As method, philosophical anthropology looks at man in terms of the inherent relationship between his inner and outer being. Unlike Desecration monistic view, philosophical anthropology suggests that man does have spiritual -often called intuitive- dimension that would count him as true man. This approach also runs counter to the many sciences such as biology, economics, linguistics, sociology and psychology, which often -even always- look at man in a monistic way by giving attention only to his outer dimension.

Speaking in a broad generality, philosophical anthropology looks at man not only as an object but more importantly as a subject. He is an active being, the creator of his own history and the inventor is his own future. In the context of modernity, this view of man is very important particularly because it poses a challenge to the hegemonic doctrine that places man as an object treated as it were as a mere goods or slave. ${ }^{4}$

Within the context of modernity, one may ask whether sciences born out of its womb can still be called a science. This question is legitimate because some of these sciences have lost their credibility by claiming to be the only representative of the objective truth. ${ }^{5}$ And this claim is seemingly common. Dogmatism has been prevailing in the scientific realm. On a regular basis one would see a scientist rejecting

Anthony J. Lisska, Aquina's Theory of Natural Law: An Analytic Reconstruction (Oxford: Clarendon Press, 1996). For him, rationality is the principle of movement, hence the source of - say - spirituality. For the sufis, I would argue, the opposite is true. That is, spirituality is the principle of human action, hence the source of rationality.

${ }^{4}$ The modern views that stress on the materialistic side of human being have perfectly been represented by such philosophical current as materialism and positivism. Philosophers such as Auguste Comte, Herbert Spencer, Karl Mark, Ludwig Feuerbach, Soren Kierkegaard, John Dewey, David Hume, Emile Durkheim and above all Charles Darwin belong to this school of thought.

5 Contemporary philosopher such as Paul Feyerabend has launched an attack against what he calls epistemological anarchism. His ultimate aim is indeed to improve science and to encourage the growth of knowledge. But what is astonishing is his finding that many methods proposed by modern scholars are indeed anarchistic and imposing. See Paul Feyerabend, Against Methods (London: Verso, 1993). 
other scientific findings as objective claiming that his/her theories and methods vis-à-vis others are the only valid ones. These claims are naïve for a science is supposed to be open, flexible and always evolving.

Philosophical anthropology may also be dogmatic and absolutistic like any others. But because of its reflective and philosophical approach, it can easily be awaken from its anthropological sleep, borrowing Michel Foucault. ${ }^{6}$ Dogmatism and absolutism in science must be seriously dealt with and addressed properly or else the future of science -and consequently of man- may be in danger. The very fundamentals of science -that is its approach and method- must be deconstructed by means of introducing new ways of looking at things. Philosophical anthropology is meant to be the candidate of that new way due its dynamic and open nature.

Philosophical anthropology itself may not be considered new. This paper however, remains interested in it not only because of its dynamism but also because of its flexibility; flexibility that makes it capable of being developed and merged. And this paper tries to merge it with the spiritual dimension of Islam called tasawuf, the result of which being the Anthropology of Tasawuf.

Interestingly, both philosophical anthropology and tasawuf are concerned not only with the notion of man, but also with the idea of how man is related to his knowledge. To be more precise, these two forms of knowledge while delving into the epistemology of man are also concerned with the methodology of how man's knowledge may be acquired. This makes the merge between the two even more possible.

One may indeed questions the possibility of the merge between the two sciences given that the one is rational while the other is intuitive. The truth of the matter is that, the history of man has witnessed that two different things can be combined. Tasawuf and philosophy for instances, are always different and even opposed to one another in terms of their method and subject-matter. Yet, they are reconcilable. ${ }^{7}$

\footnotetext{
${ }^{6}$ In his The Order of Things, Foucault allocates one particular section which he calls Anthropological Sleep. See Michel Foucault, The Order of Things: An Archaeology of the Human Sciences (New York: Pantheon Books, 1970), p. 340.

7 The perfect of example of the marriage between philosophy and tasawuf in Islamic intellectual tradition is that of Shihabuddin Yahya Suhrawardi's. See Abdul Kadir Riyadi, Arkeologi Tasawuf. Melacak Jejak Pemikiran Tasawnf dari al-Mubasibi bingga Tasawnf Nusantara (Bandung: Mizan, 2016).
} 
For this reason, we contend that philosophical anthropology and tasawuf may be brought together and -as method- can be used to analyze such philosophical issue as man. It is this that we intend to do here by looking at the thought of Surabaya-based sufi Shaikh Ahmad Asrori concerning not only man, but also -and this is more importantof his essence.

The problem of man's essence itself has been the foci of analysis by specialist across centuries. But the multi-faceted nature that it has poses many question unresolved. What really is the essence of man remains the very fundamental and intriguing question to answer.

Philosophy represents one of the most serious sciences when it comes to the question of man's essence. Scientists owe a great deal to philosophers for what they have done. For many -if not all philosophers- the concept of man's essence constitutes the most important aspect of being. Man cannot be properly understood unless his essence is fairly exposed.

What philosophy has done to juxtapose the idea of man's essence in the past millennia or so has indeed contributed to our understanding of not only man but also of being in general. The efforts that the philosophers have done to unearth the very essence of man have indeed helped us to understand what man and being in general are all about. Thanks to its approach and method, we now have at our disposal sufficient and fair information about this mysterious being. And it is exactly for this reason that using the philosophical approach remains of paramount importance when it comes to the problem of man's essence.

Philosophical approach has the advantage of being fundamentally radical, theoretical, critical, reflective, classifying, and dichotomizing. All these make it flexible and general, and hence capable of dealing with almost every existing thing not by looking at its superficiality but at its essence.

Philosophers of the past and the present of all currents of thought are regular users of such an approach. Philosophers such as Ibn Arabi, Suhrawardi al-Maqtul, Ibn Rushd, Ibn Hazm and Ibn Khaldūn in the past, Hassan Hanafí, 'Alī Sharī'atī, and even the more "traditional" thinkers such as Yūsuf al-Qarḍāwī and Muhammad al-Ghazālì at the present are fond of it in their own way. Scholars of the past who are deemed anti-philosophy are in fact proponent of it, such as Abū Ḥāmid al-Ghazālī,. 
Al-Ghazali was without doubt, one of the strongest proponents of philosophy in Islamic tradition although he was also paradoxically its staunchest critic. ${ }^{8}$ Suhrawardī al-Maqtūl -more than al-Ghazālī- was an all-round philosopher in the truest sense of the word. He was the heir of not only al-Kindi, al-Farabi and Ibn Sina, but also of Socrates and Plato. He combined the Islamic and Greek intellectual legacies resulted in the new form of current he calls Philosophy of Illumination (Istishraqiyah), which Hossein Ziai describes as the best sufistic philosophy ever. ${ }^{9}$

It is this kind of integrative and synthetic mode of thinking intrinsic within philosophical approach that we speak about here as the very nature of the anthropology of tasawuf. As its name suggests, this proposed approach speaks of man not only in terms of his material being, but also of his spiritual and intellectual entity.

To be more precise -as far as its object is concerned- the anthropology of tasawuf delves into the notion of man's essence and how he may acquire knowledge. Within this context, man is understood as the "knowing spiritual subject". He is a "subject" because he has the internal capacity to be independent capable of shaping his own future. He is also responsible for his own act before God. He is then "spiritual" because of his very religious and intuitive nature. Man is -by his very upbringing- in a continuous search of God, the centre of the universe. Man cannot be looked at simply as an empirical being, for he is imbued with mind, heart and soul whose task it is to go beyond his own sensory world and move to the transcendental one. He is finally "knowing being" simply because what differentiates him from others is precisely his knowledge.

These are the three aspects of the anthropology of tasawuf as far as the concept of man is concerned. In this way, it resembles Frithjof Schuon's spiritual anthropology for both are equally concerned with man from the epistemic and spiritual perspective. Schuon himself has tried to merge anthropology with tasawuf through his From the Divine to the Human. In his view, man consists of two main ingredients, namely knowledge and love, intelligence and feeling, intellect and sentiment, mind and heart. These two ingredients together produce the third one,

8 See for instance, Yasin Ceylan, "Al-Ghazali Between Philosophy and Sufim," American Journal of Islamic Social Sciences, vol. 12: pp. 584-589

${ }^{9}$ Hossein Ziai, Subrawardi dan Filsafat Iluminasi, transl. Afif Muhammad and Munir Muin (Jakarta: Sadra, 2012), p. 23. 
which is strength. These three constitute the most fundamental aspect of human being. ${ }^{10}$

Schuon also reject the Western view of man which regards him only empirically or rationally as may be found in the positivistic philosophy. This current of philosophy -in his view- does not recognize what he calls the "subjective aspect" of human being such as intuition and feeling. Although this aspect of man cannot stand independently from the so-called objective one, this latter cannot equally stand apart from the former. Hence, the two are interdependent and together form the totality of man's existence.

\section{Tasawuf as the Anthropological Category}

Scholars and specialists of tasawuf especially of the Western background have tried since 1970's to develop a kind of study that would look at it from the anthropological and sociological point of view. Their proposition is mainly centered around the idea of man as a social being. Hence, the concept of man in tasawuf in their proposition is analyzed within this framework. Tasawuf is equally presented not as a spiritual set of doctrines but merely as a social system and phenomenon.

Behind such approach and project are scholars like Clifford Geertz, Ernest Gellner, Michael Gilsenan and the like. The three are influential in their own right both in the West and in Islamic world. They have crafted an intellectual tradition that the Muslims themselves have failed to do so. Geertz is seemingly the most familiar among them particularly in Indonesia. He speaks mostly of religious symbol and religion as a cultural system. He sits down in a Javanese village called Mojokuto for many years and produced a seminal called The Religion of Java. For many decades since its publication, the work has and perhaps still is- exerted a strong influence among the students of religion and mysticism particularly in Indonesia. ${ }^{11}$

Another work by Geertz of equal standing is Islam Observed: Religious Development in Morocco and Indonesia. This work portrays the religious development of the two countries comparatively and found as might be expected- both similarities and differences in the religious

\footnotetext{
${ }^{10}$ Frithjof Schuon, From the Divine to the Human (USA: World Wisdom Books, 1981), p. 77.

${ }^{11}$ See Clifford Geertz, The Religion of Java (Chicago: Chicago University Press, 1976).
} 
culture and symbolism. The theories proposed in this work have been a subject of debate among scholars especially on the nature and role of religious leaders in the creation of religious symbol. ${ }^{12}$

The two works by Geertz have made him an authoritative giant in the field of sociology of religion and won him a widespread recognition as one of the most leading -yet controversial- scholars in this realm. Among the controversy that he invented is his understanding of religion as a cultural system. ${ }^{13}$

Gellner in the meantime, is quite distinctive in his method, approach and subject-matter. While Geertz distances himself from anything Islamic and chose rather to call the religious phenomenon in Java for instance, as a Javanese religion, Gellner seems to have no problem whatsoever in appreciating what he thinks as "Islamic". He is familiar with not only such philosopher as David Hume, but also with Ibn Khaldun. Hence, his is an amalgamation of the East and the West, of the positivistic nuance and religious gist.

Doing his research mostly in Morocco, Gellner is interested particularly in the social function of the Sufis. He wrote Muslim Society documenting the Sufi practices and their social ramification. This work represents his academic quality and speaks volumes as far as the need for the sociological research of the Sufis is concerned. ${ }^{14}$

Unlike Geertz and Gellner, Michael Gilsenan is not the type of person that would bring forward new proposition. He is mainly interested in describing social phenomenon surrounding the Sufis and their activities. Although he does not open new possibilities in the study of tasawuf, he is quite critical in what he is doing. He wrote Saint and Sufi in Modern Egypt. An Essay in the Sociology of Religion published in 1973 and Recognizing Islam: Religion and Society in the Modern Middle East published in 1992. The two works -due to their rich information-

\footnotetext{
12 See Clifford Geertz, Islam Observed. Religious Development in Morocco and Indonesia (USA: University of Chicago Press, 1968).

${ }^{13}$ To have the sense of how Geertz exercised his influence in the study of religion, and how he has come under severe criticism from his critics, see for example Katherine E. Hoffman, "Culture as Text: Hazards and Possibilities of Geertz's Literary/Literacy Metaphor," The Journal of North African Studies, vol. 14, Nos 3/4 September. See also Talal Asad, Genealogies of Religion: Discipline and Reasons of Power in Christianity and Islam (Baltimore: The Johns Hopkins University Press, 1993).

${ }^{14}$ Ernest Gellner, Muslim Society (Great Britain: Cambridge University Press, 1995), pp. $1-85$.
} 
become the necessary sources for one studying tasawuf in the modern Egypt and Middle East as well as the spiritual phenomenon in the modern world. ${ }^{15}$

The three scholars represent a new generation of researchers that give much -if not all- their attention to the social and anthropological aspects of tasawuf by emphasizing -among others- the social function of the Sufis. This sort of trend in research continues until now, with fluctuating reception among scholars in this field. Speaking in broad generality, this trend can be found in almost any university particularly in the West with a strong academic tradition. In Islamic world, speaking of Islam and tasawuf sociologically and anthropologically is often overshadowed by speaking it normatively or theologically.

Recently however, countless works have been written in the field of the sociology of tasawuf. Prominent among these include Julian Johansen's Sufism and Islamic Reform in Egypt: The Battle for Tradition, ${ }^{16}$ Mark Sedgwick's Saints and Sons: The Making and the Remaking of Rashidi Abmadi Sufi Orders, ${ }^{17}$ and many more.

In Indonesia, research of this kind has been undertaken in many ways and by many local and international scholars. Martin van Bruinessen is the most familiar researchers in this regards whose work on pesantren, tasawuf and Islam in the Archipelago have won him a widespread recognition from inside and outside the country. Recently, in collaboration with Julia Day Howell, he wrote Sufism and the "Modern" in Islam, which has been translated into Bahasa Indonesia. ${ }^{18}$ Julian Millie, a lecturer of anthropology at Monash University wrote his $\mathrm{PhD}$ thesis on the tasawuf of Abah Anom. He is also quite serious in paying attention to the tasawuf of Ahmad Asrori and his magnificent sufi order based in Surabaya called Tarekat Qadiriyah wa Naqshabandiyah.

\footnotetext{
${ }_{15}$ Regarding these two books, see Michael Gilsenan, Saint and Sufi in Modern Egypt: An Essay in the Sociology of Religion (USA: Clarendon Press, 1973), and Michael Gilsenan, Recognizing Islam: Religion and Society in the Modern Middle East (New York: Pantheon Books, 1992).

${ }^{16}$ See Julian Johansen, Sufism and Islamic Reform in Egypt: The Battle for Tradition (Oxford: Oxford University Press, 1996).

${ }^{17}$ See Mark Sedgwick, Saints and Sons: The Making and the Remaking of Rashidi Abmadi Sufi Orders, 1799-2000 (Holland: Brill, 2005).

18 See Martin van Bruinessen and Julia Day Howell (eds), Sufism and the "Modern" in Islam (USA: I.B. Tauris, 2007).
} 
Decades before them, tasawuf in Indonesia has received a serious attention from the like of Anthony H. Johns who in 1961 published his seminal paper on the Sufism as a Category in Indonesian Literature and History. ${ }^{19}$ Using historical and anthropological approach, the work has been regarded as one of the best in this field regardless of the controversies it has invented and somewhat careless proposition it has developed.

It is worthwhile mentioning in this context that the local scholars have also participated in exposing the many facets of tasawuf in Indonesia. Some of their works are published in Bahasa Indonesia, while others in English. Among the latter category is that of Arif Zamhari's $\mathrm{PhD}$ thesis presented to the Australian National University in 2010 entitled Rituals of Islamic Spirituality: A Study of Majlis Dbikr Groups in East Java. ${ }^{20}$

The intensity of research on the sociology of tasawuf cannot by underestimated. While it indicates the importance of the subject, it also symbolizes the renaissance of tasawuf. It should be stated here that despite the resistance of some normative ulama who regard this approach as meaningless, the fact remains that even the classical ulama such as al-Biruni (d. 1048) spent a great deal of time to write work of sociological nature. His Kitab al-Hind (The Book of India), speaks of not only the history of India, but also of its culture, customs, rites, belief system, religious practices and so on. ${ }^{21} \mathrm{By}$ all account, it is fair to say that the sociological research on tasawuf in particular and religion in general has helped us not only to accentuate the importance of this subject but also to emancipate it from being simply social phenomenon into becoming an "epistemological category".

Tasawuf itself should be regarded as an epistemological category. We are indebted to $\mathrm{A} \mathrm{H}$. Johns who -in this regard- has launched campaign decades ago to emancipate tasawuf as an epistemology. By an "epistemological category" he simply means a discourse or concept

\footnotetext{
${ }^{19}$ See AH Johns, "Sufism as a Category in Indonesian Literature and History," Journal of Southeast Asian History, Vol 2, No 2, p. 14.

20 Arif Zamhari, Rituals of Islamic Spirituality: A Study of Majlis Dhiker Groups in East Java (Australia: ANU E-Press, 2010), pp. 13-14.

${ }^{21}$ Akbar S Ahmad treats al-Biruni as the first Muslim anthropologist and describes him as, "the many-sided genius". See Akbar S. Ahmad, Discovering Islam: Making Sense of Muslim History and Society (Great Britain: Routledge, 2001), pp. 98-99.
} 
of epistemology, a set of theory or knowledge. ${ }^{22}$ For him -like many others- tasawuf is not only a set of practices, or a compilation of rites and ceremonies. It is after all a paradigm. It is a category because -in Indonesian context- it has become a current of thought and shaped the very national identity of Indonesian Muslims.

Now, while the arguments that Johns has tried to develop are limited within the context of literature and history, here we try to contend that tasawuf is a category not only historically and in terms of literature, but also anthropologically. It means that tasawuf should be looked at as a concept particularly of man and knowledge. So, what is proposed here is a discursive jump from the so-called social anthropology into the transcendental anthropology; from that which looks at man simply as a social being into that which sees him as a spiritual and intellectual existent.

The same jump has been undertaken by the like of Pnina Werbner. Through a work on the Naqshabandi Sufi Order in Pakistan, she proposed a new form of anthropology which may be called the cosmological anthropology. Through this work, she criticizes the propositions of social anthropologists that she thinks have mislead the most basic and fundamental doctrine of tasawuf. ${ }^{23}$ She then tries to transform anthropology to cover concepts about universe (cosmology), being (ontology), and the relationship between the two. This kind of anthropology necessitates that when a particular issue within tasawuf is discussed, it is done so within the perspective of cosmology and ontology.

Our anthropology is somewhat similar to Werbner's in the sense of being transformative. But ours differs with hers in terms of its direction. While Werbner's anthropology turns into cosmology and ontology, ours is directed toward epistemology and spirituality. This latter form of anthropology in the words of Kenneth Lizzio is called the "transcendental anthropology". ${ }^{24}$

\footnotetext{
22 Ibid., pp. 11-17

${ }^{23}$ See Pnina Werbner, Pilgrims of Love: The Anthropology of a Global Sufi Cult (London and Bloomington: Hurst Publications and Indiana University Press, 2003).

${ }^{24}$ Kenneth Lizio, "Pilgrims of Love: An Ethnography of a Global Sufi Cult". The Muslim World, vol. 95 (Britain: Blackwell Publishing Limited, 2005), pp. 607-608.
} 


\section{Ahmad Asrori's Anthropology of Tasawuf}

Having discussed the theoretical framework of what anthropology of tasawuf is, it is now time to bring forward the thought of Surabayabased Sufi master named Ahmad Asrori (d. 2009) concerning man. Like any other philosophical Sufi, Asrori speaks of issues reminiscent of the anthropology of tasawuf such as the issue of insan kamil, man as micro-cosmos, Muhammad's essence, Muhammad's light and the like.

Asrori was the murshid of Qadiriyah wa Naqshabandiyah (TQN) Sufi Order. His charisma, leadership quality, intellectual acumen and spiritual depth have won him a huge respect from millions of people across Java in particular and the whole Archipelago in general. His students and followers are to be found not only in Indonesia, but also in Malaysia, Singapore, Thailand and even Australia. Little has been done however, to study his thought critically and to understand better the nature of his message. The study of his order is equally limited. ${ }^{25}$

The TQN was established before him by Shaikh Ahmad Khatib alSambasi (d. 1875). Asrori inherited the leadership of the order from his father Shaikh Muhammad Utsman al-Ishaqi (d. 1984). The extent of Asrori's influence on the Order, and its massive expansion and progress may be measured among others by the visit of the sixth president of the Republic of Indonesia, Susilo Bambang Yudhoyono to his headquarter in 24 June 2009.

While the TQN has continued to grow and succeeded in recruiting new members in a quite significant number, the same is unfortunately not the same with Asrori's thought, which has not received a reasonable attention from his closets disciples let alone from the outsiders.

Asrori wrote al-Muntakhabat (The Selected Texts). As the name indicates, the work is actually a collection of various texts by different Sufis on various spiritual doctrines. Hence, the book may be labeled a commentary. But unlike any other commentaries, the book does not focus on one work by a particular Sufi. It is actually a collection of various texts, making it perhaps an encyclopedia-like work.

Apart from the way it is written, the work is precious in its own right. Speaking philosophically of various issues related to the concept of man, knowledge and Shari'ah, the work can be regarded as part of the intellectual tradition to which the like of Ibn Arabi, al-Ghazali, al-

25 Among the few that has done a research on the TQN is Ahmad Amir Aziz, who submitted his PhD thesis to Sunan Ampel State Islamic University in 2013. 
Jilani and many others like them belong. Judged at face value, the work is part of the sober efforts to maintain the chain of the Sufi intellectual tradition in which knowledge is cherished, man is given special role in the cosmos, and religion as well as morality is upheld firm. It is part of that discourse in which ideas are continuously invented and thoughts are both developed and preserved.

Despite some ambiguities found in it in terms of its system, narratives and even content, the work remains unique considering that it is the only work written in Arabic by an Indonesian Sufi master in recent times.

Al-Muntakhabat was written few years before Asrori passed away. The Indonesian version of the book is also available. In its Arabic edition, the book consists of two volumes each of which comprises of 565 pages (first volume) and 664 pages (second volumes). The method that the author follows in writing the book is to relate passages of certain issue by a certain sufi, then providing comments on those passages. Upon providing comments or notes, he would normally precede by saying, "qultu" (I say). This way of writing is common among scholars of traditional academic circle in classical Java.

The first issue that Asrori deals with in the book is the notion of Muhammad's Light (al-Nur al-Muhammadi). One does not need to be expert to realize that this is a philosophical issue. On this topic, Asrori seems to have related himself -and he actually did- with the school of Ibn Arabi and Abdul Karim al-jili as well as with the academic tradition found in the Archipelago to which the like of Hamzah Fansuri (d. 1590) and Yusuf al-Makassari (d. 1699) belong.

On this topic, Asrori speaks of -like Ibn Arabi and al-Jili- the idea of the essence of Prophet Muhammad's self. For him, Muhammad's self is none other than the representation of man's ultimate perfection. To be prophet is to be perfect as man both spiritually and intellectually. And that perfection is ultimately symbolized in him being called the "light". Hence, the light of Muhammad is about his ultimate perfection otherwise identified as spiritual illumination and intellectual maturity. ${ }^{26}$

In the second chapter, Asrori speaks of the idea of the essence of Muhammad's prophethood. Like Muhammad's self, his prophethood

26 Ahmad Asrori, Al-Muntakhabat fi Rabithah al-Qalbiyah wa Silah al-Rubiyyah, vol. I (Surabaya: al-Khidmah, 2007), pp. 13-14. 
is also reminiscent of perfected knowledge and spiritual illumination, of high order thinking and intuition symbolized in light.

Self and prophethood are two things that supposedly complement each other. But Asrori does not speak about it although he seems to realize that they represent the same thing, which is human perfection. One may speculate that Muhammad's self is a symbol of his perfection as human, while prophethood is a symbol of his perfection as a messenger of God.

What is intriguing is Asrori's discussion of what he calls Surab Muhammadiyah (Muhammad's Exterior Outlook), which he thinks as belonging to Muhammad's prophethood, rather than to his self. What are the criteria that make the prophet exterior outlook part of his prophethood is not at all clear. Also, in what way this outer outlook is related to his prophethood, and whether this exterior outlook is really related to his prophethood -and not to his light or inner self- is not elaborated. One is left curious about this issue.

Be that as it may, Asrori makes another point in an effort to connect his view with the previous one; a point that makes one becomes even more curious. He reckons that what is meant by Muhammad's exterior outlook is not his physical dimension. It is rather the essence of that physical dimension. He makes a sharp distinction between the essence of this exterior outlook and a mere physical outlook. For him, the former is important while the latter is not. His argument is such that Muhammad's prophethood does not have anything to do with his physical aspects.

This means that al-Surab al-Mubammadiyah, that is, the essence of Muhammad's physical dimension is the prophethood itself. The two are closely identical. If that is accepted, then the question is, with what Muhammad's light is identical? Is it not part of his prophethood? Is it something intrinsic within prophethood or imported from without? This is the question that Asrori fails to answer. In all likelihood however, it is possible that Asrori means to differentiate between a simple prophethood and a greater prophethood (al-Nubuwwah al$A$ 'zam), a view commonly propagated by Sufis. The former is the normal one, namely a kind of quality that any prophet is blessed with. The latter in the meantime, is the exclusive dominion of the prophet Muhammad where light is supposedly to be found. Accordingly, it is only prophet Muhammad that can be identified as light, while other prophets can not. 
Having explained briefly of what that essence is, Asrori then moves little bit further to conclude that the essence of his exterior outlook is none other than knowledge and mind. To put it differently, Muhammad's prohethood is identical with knowledge. The big question is then, where does the notion of revelation fit in, in the whole idea of prophethood? If prophethood is knowledge, does that mean that Muhammad is a prophet because of his intellectual perfection and not because of revelation he received? Again, the answer for these questions is not to be found anywhere in alMuntakbabat.

Nor is the discussion on the so-called interior dimension of the prophet to be found in the work. One does expect that since the author speaks of the exterior dimension, he would speak too of the interior aspect. In the absence of such discussion, one can probably assume that while the exterior side of the prophet refers to the essence of his physical dimension, the interior one -if any- should refer to the essence of his spiritual dimension. Consequently, while the exterior dimension is to do with knowledge and mind, the interior one should logically speaking- be related to spirituality on the one hand, as well as revelation and the Holy Scripture on the other.

If this is accepted -and I think it should- then the structure of Asrori's thought as far as the concept of prophethood is concerned can be interpreted within this framework. Accordingly, man has two dimensions, the first is exterior that -when perfected- leads to an intellectual perfection, and the second is interior that leads to the spiritual illumination. The ultimate perfection of man is duly represented by the prophet Muhammad who -by virtue of his intellectual and spiritual quality- has acquired light and becomes himself light. This means that prophethood is none other than a perfect combination of knowledge and spirituality, of mind and heart, of rationality and intuition.

Speaking particularly of knowledge, Asrori elaborates it in a somewhat great length. In an unexpected manner, he presents himself as a rational philosopher and identifies knowledge as the "first pen" and the "first mind". He states, "there are key terms that one should understand properly with regard to the essence of Muhammad's prophethood. Such terms as the first pen and the first mind are all 
related to prophethood and refer to the idea of Muhammad's knowledge". 27

These terms are known among early philosophers and Sufis of Islam such as Abu Hamid al-Ghazali, and have been used to denote knowledge. ${ }^{28} \mathrm{Al}$-Ghazali -as Ebrahim Moosa has rightly indicated- is fond of using the term pen and mind to signify the importance of knowledge. In al-Ghazali's poetics, knowledge is being symbolized by pen because it is through pen that knowledge may be written. Similarly, knowledge is also represented by mind because it is only through mind that knowledge can be elaborated.

Aiming at putting more emphasis on the significance of pen and mind, Asrori further writes, "know, that each and every form of knowledge has its own peculiar terms explaining the key concepts of that knowledge". ${ }^{29}$ By this passage, he means to say that pen and mind are the most central terms in the spiritual and intellectual science through which man may acquire knowledge.

The role of pen and mind in acquiring knowledge receives further attention when Asrori moves on to cite prophetic saying about the role of mind. He narrates that that the prophet said, "the first thing God created is the light of the prophet". Asrori comments that what is meant by "the light of the prophet" is actually his mind. ${ }^{30}$

What Asrori is trying to say is that the role of mind -hence of rational knowledge- in the whole structure of Islamic epistemology is not only endorsed by the Muslim scholars, but also by the prophet himself. Hence, rationality is the very basis of all forms of knowledge in Islam. This goes in line with the fact that knowledge -any knowledge- is the product of mind, while religion is the criterion of revelation. Although religion might have a role in the production of knowledge, it is ultimately human mind that works into play when it comes to the invention of knowledge.

Within this context, Asrori makes a strong point. He contends that even makrifah -the highest form of spiritual knowledge- is rational. In

\footnotetext{
27 Ibid., p. 31.

28 See Ebrahim Moosa, Ghazali and the Poetics of Imagination (USA: The University of North Carolina Press, Chappel Hill, 2005), pp. 106-107.

${ }^{29}$ Asrori, Al-Muntakhabat fi Rabithah al-Qalbiyah, p. 31.

${ }^{30}$ Ibid., p. 22.
} 
his words, "al-ma'rifatu bi al-'aqP",31 the translation of which can be, 1) makrifah is the product of mind, or 2) makrifah is acquired through mind. Both mean that knowledge has nothing to do with religion. It has to do with -and comes out of the womb of- mind or alternatively intellect.

It is not coincidence that having completed his mission in building his Sufi Order -and hence in developing the practical side of tasawufhe is now concerned through al-Muntakhabat, with directing it toward its epistemological aspect. His vision is clear; through the TQN he teaches the students to proper practices and rites, while through alMuntakhabat he guides them toward the proper understanding of tasawuf.

If we put this in the background, then one should read alMuntakhabat in the context of Asrori's effort to drag the Sufi Order into its discursive realm. The reason for this is clear; many Sufi orders have lost their intellectual enthusiasm and are aspired only toward its ritual activism.

This is not to say however, that a sufi order should be emptied from its ritual and practical aspect. This is rather to say that the order should be based on a proper understanding of tasawuf and be aspired toward the production of knowledge. And if one is to choose between practicing sufi order and acquiring sufi knowledge, he/she should definitely choose the latter without certainly underestimating the former. That is what Asrori himself has taught. In al-Muntakbabat he speaks exclusively of knowledge citing intensively from such intellectual figures as Ibn Arabi and al-Ghazali as if he associates himself with them than with the like of Abdul Qadir al-Jilani.

This clearly indicates that Asrori belongs to the sufi intellectual tradition in which rationality is given a great deal of preference. He is part and parcel of the Ibn Arabian tradition whose history in the Archipelago spanned from the 17th century Hamzah Fansuri in Aceh and Yusuf al-Makassari in Makassar to the $19^{\text {th }}$ century Umar Nawawi al-Jawi in Banten. He is too the heir of the Ghazalian tradition whose existence in the Archipelago has shaped the very history of the nation particularly through the cultural and educational role of the Pesantren.

Although Asrori did not mention any of his early Indonesian Sufi masters in his work, but his ideas have a great deal of similarities with

${ }^{31}$ Ibid., p. 21. 
their thought and found the same ground in al-Ghazali and -to a larger extent- Ibn Arabi.

It is quite interesting that in al-Muntakhabat, Asrori does not stop discussing the notion of mind in the first and second chapters. He moves further and continues all the way to the $10^{\text {th }}$ chapter. With various and different intensity, in these 10 chapters he keeps on emphasizing the importance of mind not only in producing knowledge but also in strengthening one's piety and even faith. He reminds us about a prophetic saying in which the prophet is reported to have said, "O Uwaimir, be a mindful man so that you may become closer to your Lord". 32

Now, while in the first 10 chapters he deals -generally speakingwith the perfection of man symbolized in an intellectual and spiritual maturity and is represented ultimately by the prophet, in the next chapter he emphasizes his point by explaining the essence of man. He states that the essence of man lies in his spirituality. ${ }^{33}$ This complements his previous proposition that the ultimate perfection of man lies not only in his spirituality but also in his mature intellectuality. But here, he emphasizes only on the spiritual side leaving aside for a moment the other side.

In the subsequent chapters of al-Muntakhabat, he discusses the place of Shari'ah not only in the structure of Islam as a religion but also in its epistemological system. He maintains that Shari'ah is the basis for all forms of science in Islam. Any science in Islam must stem from it, and should reflect its values. All forms of science are none other than the ramification and reification of Islam.

Asrori reckons that there are four forms of science that may be classified as belonging to the realm of Shariah. These are, 1) the narrated science, namely science narrated by the past trusted scholars, 2) the revealed science including jurisprudence and other sciences that has to do with the law of Islam, 3) the science of analogy and rationality such as kalam and the foundation of jurisprudence (ushiul al figh), and 4) the science of hakekat, the highest form of all science. ${ }^{34}$

Hence, in the mind of Asrori, hakekat is a branch of Shari'ah and cannot be divorced from it. Once a science -hakekat included- is

\footnotetext{
32 Ibid., p. 85.

33 Ibid., p. 97.

${ }^{34}$ Ibid., p. 188.
} 
divorced from Shari'ah then it will loose its legitimacy. Like Ahmad Sirhindi in India, Asrori champions Shari'ah as occupying the very center of Muslims life and regards it as the foundation of the Islamic epistemology.

What Asrori means by the science hakekat is none other than tasawuf. Although he does not make any explanation about this, it is quite common to associate hakekat with tasawuf.

What is important to note here is that al-Muntakhabat represents part of Asrori's systematic campaign to propagate tasawuf as part of Shari'ah and that tasawuf should be submerged within it. In an empathic manner, he remarks that, "the kind of tasawuf that I propagate is that which follows the norms of Shari'ah, enlightens the path of tarekat and leans toward the hakekat".

If anything matters the most to Asrori, it is Shari'ah. Tasawuf is the spiritual side of Shari'ah. All Muslims' acts, their thought and ideas must be based on Shariah. Tasawuf and philosophy in the whole structure of Shari'ah represent its branches whose task is to discover its secret by means of -in the case of tasawuf- spiritual undertaking, and in the case of philosophy- scientific and rational investigation.

\section{Conclusion}

What this paper has sought to do is to discover-by employing the approach of the anthropology of tasawuf- the essence of man and how he acquires knowledge in the thought of Ahmad Asrori. The paper believes that Asrori had in mind that man is a "knowing spiritual being". Asrori spoke of aspects of tasawuf that may be analyzed within the methodological framework of the anthropology of tasawuf; something that this paper has left out for the future researchers. These aspects include the concept of man as a microcosm, the notion of sainthood, perfect human being (al-insan al-kamil), the concept of ma'rifah and others.

This paper find an argument concerning Asrori's conception of man; that man in his mind is a knowing spiritual being by virtue of him being the potentials to develop his spiritual experience and rational ability. Nonetheless, the teachings of Asrori go along the line of what might be called the "traditional Sufi school of thought" on the ground that he champions Shariah as foundation for both religion and knowledge. But Asrori seems to have believed also that this divine 
canon should continuously be interpreted from the lenses of spirituality and rationality.

Like Asrori, the anthropology of tasawuf seeks to promote that knowledge cannot be based solely on revelation. The role of man as an interpreting agent should be recognized too. But in undertaking the task of interpreting religion, man must have a method. And that method can be developed out of man's spiritual experience and his rationality.

Anthropology of tasawuf therefore accepts the sufistic premise that an intuition is the source of knowledge just as rationality -in its various forms- is also a legitimate way of knowing. The word "anthropology" in the final analysis implies that knowledge must be ultimately rational -or alternatively empirical- while the word "tasawuf" means that knowledge must be practically beneficial.] 


\section{References}

\section{Books and Articles}

Abidin, Zainal. Filsafat Manusia: Memahami Manusia Melalui Filsafat. Bandung: Remaja Rosdakarya, 2006.

Ahmad, Akbar S. Discovering Islam: Making Sense of Muslim History and Society. Great Britain: Routledge, 2001.

Asad, Talal. Genealogies of Religion: Discipline and Reasons of Power in Christianity and Islam. Baltimore: The Johns Hopkins University Press, 1993.

Asrori, Ahmad. Al-Muntakhabat fi Rabithah al-Qalbiyah wa Silah alRuhiyyah. Surabaya: al-Khidmah, 2007.

Ceylan, Yasin. "Al-Ghazali Between Philosophy and Sufim." American Journal of Islamic Social Sciences. vol. 12, 1995.

Cook, D. Theodor Adorno: Key Concepts. Durham: Acumen, 2008.

Derrida, Jacques. Margins of Philosophy. transl. Alan Bass. Chicago: Chicago University Press, 1982.

Feyerabend, Paul. Against Methods. London: Verso, 1993.

Foucault, Michel. The Archaeology of Knowledge and the Discourse of Language. transl. AM Sheridan Smith. London: Routledge, 1969.

-------. The Order of Things: An Archaeology of the Human Sciences. New York: Pantheon Books, 1970.

Geertz, Clifford. The Religion of Java. Chicago: Chicago University Press, 1976.

------. Islam Observed. Religious Development in Morocco and Indonesia. USA: University of Chicago Press, 1968.

Gellner, Ernest. Muslim Society. Great Britain: Cambridge University Press, 1995.

Gilsenan, Michael. Saint and Sufi in Modern Egypt: An Essay in the Sociology of Religion. USA: Clarendon Press, 1973.

-. Recognizing Islam: Religion and Society in the Modern Middle East. New York: Pantheon Books, 1992. 
Griffin, David Ray. Spirituality and Society: Postmodern Visions. New York: SUNY, 1988.

Habermas, Jurgen. Religion and Rationality: Essays on Reason, God and Modernity. Cambridge: Cambridge University Press, 2002.

Hoffman, Katherine E. "Culture as Text: Hazards and Possibilities of Geertz's Literary/Literacy Metaphor." The Journal of North African Studies. Vol 14, Nos 3/4 September 2009.

Johansen, Julian. Sufism and Islamic Reform in Egypt: The Battle for Tradition. Oxford: Oxford University Press, 1996.

Johns, Anthony H. "Sufism as a Category in Indonesian Literature and History." Journal of Southeast Asian Studies. Vol 2, No 2, 1961.

Lisska, Anthony J. Aquina's Theory of Natural Law: An Analytic Reconstruction. Oxford: Clarendon Press, 1996.

Lizio, Kenneth. "Pilgrims of Love: An Ethnography of a Global Sufi Cult." The Muslim World, Vol 95, 2005.

Moosa, Ebrahim. Ghazali and the Poetics of Imagination. USA: The University of North Carolina Press, Chappel Hill, 2005.

Mumford, Lewis. The Condition of Man. London: Martin Secker, 1963.

Nasr, Seyyed Hossein. Traditional Islam in the Modern World. New York: Columbia University Press, 1990.

Rahman, Fazlur. The Philosophy of Mulla Sadra. Albany: SUNNY, 1975.

Riyadi, Abdul Kadir. Antropologi Tasawuf: Gagasan Manusia Spiritual dan Pengetahuan. Jakarta: LP3ES, 2013.

-------. Arkeologi Tasawuf. Melacak Jejak Pemikiran Tasawnf dari alMuhasibi bingga Tasawuf Nusantara. Bandung: Mizan, 2016.

Schuon, Frithjof. From the Divine to the Human. USA: World Wisdom Books, 1981.

Sedgwick, Mark. Saints and Sons: The Making and the Remaking of Rashidi Ahmadi Sufi Orders, 1799-2000. Holland: Brill, 2005.

Shari'ati, Ali. Tugas Cendikiawan Muslim. Transl. Amin Rais. Jakarta: RajaGrafindo Persada, 2001.

Smith, Huston. Why Religion Matters. USA: Harper Collins, 2001.

Van Bruinessen, Martin and Julia Day Howell (eds). Sufism and the "Modern" in Islam. USA: I.B. Tauris, 2007. 
Abdul Kadir Riyadi

Werbner, Pnina. Pilgrims of Love: The Anthropology of a Global Sufi Cult. London and Bloomington: Hurst Publications and Indiana University Press, 2003.

Zamhari, Arif. Rituals of Islamic Spirituality: A Study of Majlis Dhikr Groups in East Java. Australia: ANU E-Press, 2010.

Ziai, Hossein. Suhrawardi dan Filsafat Iluminasi. Trans. Afif Muhammad and Munir Muin. Jakarta: Sadra, 2012. 